Anna Modelska-Kwaśniowska

Instytut Slawistyki

Uniwersytet Opolski

http://dx.doi.org/10.18778/8088-249-2.12

\title{
KOBIECE DOŚWIADCZENIE TRAUMY WOJENNEJ W POWIEŚCI JASMINY MUSABEGOVIĆ SKRETNICE
}

Chciałabym napisać historię tej wojny. Historię kobieca.

[Aleksijewicz 2015: 10]

Jasmina Musabegović (ur. 1941) należy do uznanych współczesnych boszniackich ${ }^{1}$ prozaiczek i eseistek. Jej powieść Skretnice, którą zamierzam poddać oglądowi, Enes Duraković umieścił wśród najwybitniejszych osiągnięć literatury II pol. XX w. w Bośni [Duraković 2012: 335], a ją samą uznał za jedną z pierwszych pisarek - obok Bisery Alikadić - która naruszyła wiodący w literaturze boszniackiej dyskurs patriarchalny [Duraković 2012: 304]. W swojej twórczości (Snopis - 1980, Skretnice - 1986, Most - 1994, Žene. Glasovi - 2005) w centrum uwagi autorka postawiła pozycję muzułmańskiej kobiety w społeczeństwie bośniacko-hercegowińskim, a tematem uczyniła osobiste doświadczanie przez nią wydarzeń XX w., pisząc historię kobiecej emancypacji, ale i kobiecego osamotnienia. Podejmując ważką i nową tematykę, jednocześnie zaproponowała prozę ciekawą i intrygującą pod względem formalnym, dynamiczną i nowatorską w zakresie rozwiązań narracyjnych [Hawkesworth 2000: 262].

Enver Kazaz uznał Jasminę Musabegović za jedną z reprezentantek powieści egzystencjalnej [Kazaz 2004: 94-95], w której opowieść o jednostkowym losie jest ukazana na tle historii ze szczególnym uwzględnieniem czasów II wojny światowej. Metaforyczny tytuł Skretnice bośniacki badacz odczytuje w dwójnasób: po pierwsze, jako zwrotnice egzystencji, czyli metaforę nieustannej zmienności ludzkiego życia, po drugie - jako doświadczenie historii, które prowadzi do wniosku o braku istnienia jakichkolwiek trwałych wartości w jej toku postrzeganym jako

1 Etnonim Boszniacy obowiązuje od 1992 r., wcześniej mieszkańcy Bośni wyznania islamskiego określani byli jako „Muzułmanie”, „bośniaccy Muzułmanie” [zob. więcej: Jawoszek 2014]. 
ciągła, absurdalna zmiana [Kazaz 2004: 98]. Metafora linii kolejowej służy ukazaniu życia ludzkiego podzielonego na etapy: od stacji do stacji, aż do ostatniego przystanku².

Powieść Skretnice została także zakwalifikowana przez Envera Kazaza, jako psychologiczna powieść nowohistoryczna [Kazaz 2004: 150]. Istotą tego typu powieści nie jest ukazanie biegu historii, ale jej sensu i znaczenia dla bohatera, przemian jego świadomości, dla której historia stanowi przestrzeń metaforyzacji własnych przeżyć i stanów wewnętrznych. Podstawowym jej elementem jest prezentowanie procesu kształtowania świadomości protagonisty, śledzenie jej toku rozwojowego [Kazaz 2004: 214].

Utwór Jasminy Musabegović utkany jest z fragmentów kobiecego doświadczenia, skupiony na wewnętrznym świecie młodej muzułmanki o imieniu Fatima, który tworzą wspomnienia, sny i przeczucia. Skoncentrowanie opowieści na kobiecym doświadczeniu skutkuje uczynieniem bohaterki podmiotem samodzielnie formułującym własne relacje, ale i doznającym różnego rodzaju opresji, w tym wojennej.

Czas akcji w utworze obejmuje lata 30. XX w. oraz okres II wojny światowej, przy czym kategoria czasu nie jest traktowana ze szczególną pieczołowitością. Powieściową przestrzeń wyznacza bliżej nieokreślona prowincja bośniacka, na którą dwukrotnie zostaje zestana rodzina Faty - ku jej faktycznej rozpaczy, a także główne bośniackie miasta: Sarajewo, do którego w czasie wojny udaje się przeprowadzić rodzinie bohaterki oraz Mostar, z którego Fata pochodzi i z którym wiążą się jej wspomnienia z dzieciństwa.

Życie młodej bohaterki wypełnia głównie troska o dom i rodzinę. Wyrastający z zasad islamu system wartości, któremu hołdują bohaterowie, powoduje, że kategorie męskości i kobiecości są mocno osadzone w ramach patriarchatu. Symbolika gór i kozic patronujących Nezirowi oraz mrówek reprezentujących Fatimę dobrze oddaje sposób widzenia społecznych ról kobiety i mężczyzny. Ideologia domu i macierzyństwa w dużym stopniu potwierdza męską hierarchię wartości, miejscami tylko uwidaczniając jej niedoskonałości [Moranjak-Bamburać 2005 b]. Podział ról na pierwszy rzut oka jest stereotypowy i opiera się na

2 Całość metaforyki kolejowej ma być może pewne zakorzenienie w biografii pisarki, która przyszła na świat na stacji kolejowej w Vogošći k. Sarajewa, w powieści ma zaś uzasadnienie w tym, że mąż bohaterki, Nezir, jest kolejarzem. Powieściowa rodzina doświadcza kilkakrotnych przeprowadzek, które w jej życiu stanowią istotne zwroty, a zazwyczaj są uwarunkowane zmianami społeczno-politycznymi. W okresie wojny mieszkanie przy stacji kolejowej i obserwowanie przejeżdżających pociągów potęguje jeszcze grozę rozgrywanych wypadków, ponieważ czyni bohaterów mimowolnymi świadkami transportu ludzi do miejsc odosobnienia, obozów, a także ich mordowania. Bycie świadkiem tych procederów pogłębia traumę Fatimy. 
antynomii: mężczyzna ucieleśnia siłę, odwagę, życiową zaradność, jest żywicielem rodziny, działającym w przestrzeni publicznej, kobieta - zgodnie z przypisywaną jej rolą społeczną zakładającą opiekuńczość, odpowiedzialność za innych, traktowanie potrzeb innych z większą powagą niż własne - funkcjonuje przede wszystkim w przestrzeni domowej, jest podporządkowana mężczyźnie i oddana rodzinie. Tym samym realizuje konwencjonalną w Bośni, wpisaną w przestrzeń prywatną rolę muzułmańskiej kobiety, strażniczki wiary i tradycji, skupionej na prowadzeniu domu i wychowywaniu dzieci.

Powieściową przestrzeń tworzy głównie dom, jednak nie tylko w sensie dosłownym, ale i metaforycznym. Bohaterowie kilkakrotnie zmieniają miejsce zamieszkania, niemniej Fata w każdym kolejnym miejscu starannie organizuje życie rodzinne. Centrum życia bohaterki ${ }^{3}$ stanowi dom, a główne jej zadanie: dbałość o dobro męża i dzieci. Fatima wprowadza tematy specyficznie kobiece, czyli związane z macierzyństwem, relacjami międzyludzkimi ze szczególnym uwzględnieniem tych wewnątrzrodzinnych ${ }^{4}$. Bohaterka definiuje siebie poprzez role żony i - przede wszystkim - matki, którą to funkcję traktuje absolutnie priorytetowo, co jeszcze ulega wzmocnieniu w sytuacji wojennego zagrożenia. Jest matką pięciorga dziecis.

Centrum domu, w którym skupia się życie rodzinne, tworzy tradycyjnie kuchnia. Obowiązki kuchenne, z porannym gotowaniem kawy i wyrabianiem ciasta na chleb, wyznaczają rytm życia Fatimy. Roztaczający się zapach zakwasu na chleb i w ogóle aromaty przygotowywanych posiłków to znak normalności,

${ }^{3}$ Warto dodać, że poza Fatą pojawia się w powieści jeszcze kilka innych interesujących postaci kobiecych, które tworzą dosyć zróżnicowaną grupę. Uwzględnione są odmienności w sferze psychiki, osobowości, ale także - orientacji politycznej czy przynależności społecznej.

${ }^{4}$ Do grupy tematów specyficznie kobiecych należy także przemoc wobec kobiet, $\mathrm{w}$ tym przemoc seksualna. $\mathrm{W}$ powieści Jasminy Musabegović temat ten $\mathrm{w}$ zasadzie nie występuje, pojawia się jedynie w charakterze subtelnej aluzji, gdy Fatima w czasie wojny z przerażeniem myśli o tym, jaki los może spotkać jej dzieci i co może przydarzyć się jej córkom, ale o ile lęk przed czetnickim / ustaszowskim nożem zostaje nazwany wprost, o tyle zagrożenie gwałtem pozostaje w sferze domysłów. Być może dlatego, że jest to perspektywa tak straszna, że nie można jej zwerbalizować.

${ }^{5}$ Niejako na marginesie tematu macierzyństwa w powieści pojawia się problem aborcji, której w pewnym momencie swego życia poddała się bohaterka. Nie jest to temat tabuizowany. Fata mówi o aborcji wprost, a pieniądze na zabieg (dostępny od czasów austriackich) wymusza na niechętnym jej zamiarom mężu. Brak tutaj jakiegokolwiek ideologicznego zaplecza, bohaterka - choć funkcjonująca w ciasnych ramach patriarchatu - jawi się jako kobieta dosyć wyemancypowana, dająca sobie prawo do odrzucenia niechcianego macierzyństwa. Niechęć wobec kolejnego dziecka była związana $\mathrm{z}$ (chwilowym, ale mającym ostry przebieg) kryzysem małżeńskim. 
trwałości domowego ogniska, narażonego na liczne zawirowania. Kobiece rytuały kuchenne wiążą się z tzw. cooking memories, czyli opowieściami osnutymi wokół przygotowywania potraw czy przepisów kulinarnych, pełniącymi w czasach wojennego zagrożenia funkcję kompensacyjną. Stanowily one część strategii przetrwania w szerszym zakresie niż tylko fizyczne przeżycie [Ubertowska 2009: 214-226]. Widać to wyraźnie, gdy po kolejnej przeprowadzce Facie udaje się zorganizować przydomowy ogródek, który nie tylko daje możliwość wyżywienia rodziny w ciężkich czasach, ale i stanowi oazę w ogarniętej wojenną pożogą rzeczywistości. Uprawa warzyw w ogródku, a także przygotowywanie posiłków i ich wspólne spożywanie w ogrodowej altanie konsolidują rodzinę i dają złudzenie normalności. Obowiązki kuchenne bywają zresztą dla Faty inspiracją do zaskakujących przemyśleń: wyimaginowany obraz ścieżki, na której miałyby zostać ułożone wszystkie umyte przez nią w ciągu całego życia naczynia [Musabegović 1986: 171] wyraża autorefleksję bohaterki i silne poczucie, że jej codzienność wypełnioną jest ciężką, choć niedostrzeganą i niedocenianą na ogół pracą.

Główną sceną opowieści staje się ciało Faty, a narrację splatają takie elementy, jak codzienne przygotowywanie ciasta na chleb, metafory kolejowe, a także metafora biegu rzeki (powiązana z symboliką mostu, przywoływaną we wspomnieniach z dzieciństwa). Pojawiają się typowo kobiece symbole i motywy, ze szczególnym uwzględnieniem wody oraz ziemi, z którą Fatima odczuwa głęboką więź zwłaszcza podczas choroby, gdy jej życie jest zagrożone, a ona sama najpierw przez dłuższy czas trwa w śpiączce, a potem balansuje na granicy jawy, snu i wspomnień. Niemożność zwerbalizowania swojego cierpienia wywołuje zwrot $\mathrm{w}$ stronę świata wewnętrznego. Bohaterka $\mathrm{w}$ zestawionych na zasadzie asocjacji wspomnieniach z dzieciństwa przywołuje okres, gdy najpierw poznaje świat poprzez zmysły, dopiero potem poprzez język. Wtedy też wielokrotnie pojawia się w jej myślach, także we wspomnieniach z pierwszych lat życia, życiodajna woda. Przywołanie obrazu rodziców oraz rekonstrukcja rodzinnych opowieści związanych z tajemnicami domu i historią rodzinną stanowią ważne dopełnienie portretu bohaterki. Obrazy te są bardzo żywe, cielesne, mają charakter pozasłowny [Moranjak-Bamburać 2006]. Sugestywne opisy kąpieli w rzece, przywoływane za pośrednictwem zmysłów wzroku, słuchu i powonienia, stanowią dla bohaterki być może - rodzaj autoterapii poprzez rekonstrukcję rzeczywistości alternatywnej wobec tej, w której obecnie funkcjonuje.

Dyskurs ciała służy ukazaniu tego, co jest niemożliwe do zwerbalizowania. Nirman Moranjak-Bamburać podkreśla niemożliwość językowej reprezentacji traumatycznych doświadczeń wojennych [Moranjak-Bamburać 2005a: 198211]. Przeżycia bohaterki są relacjonowane przez pryzmat doświadczeń cielesnych. Istotną funkcję odgrywa przestrzeń szpitalna, w której przebywa Fatima w czasie swojej dość tajemniczej choroby. Jej stan, wymagający interwencji chirurgicznej, noszący znamiona choroby psychosomatycznej, związany był z narażeniem na długotrwały stres spowodowany funkcjonowaniem w sytuacji ciągłego 
zagrożenia życia swojej rodziny i własnego. Pamięć muzułmanki związana z jej chorobą i pobytem w szpitalu jest fragmentaryczna. Bohaterka ma poważne luki w pamięci uniemożliwiające jej dokonanie pełnej rekonstrukcji wydarzeń. Choroba wiąże się ponadto $\mathrm{z}$ uprzedmiotowieniem ciała, czego kobieta wielokrotnie boleśnie doświadcza. Często towarzyszy jej poczucie swoistego wyobcowania, dystansu wobec tego, co dzieje się z jej ciałem poddawanym obserwacji i lekarskiej interwencji. Fatima niezupełnie rozumie, co się wydarzyło i w jaki sposób, dlaczego trafiła na salę operacyjną. Gdy po zażegnaniu zagrożenia życia i postawieniu diagnozy trafia na salę chorych, skupia się na sobie, na własnych odczuciach, na własnym wnętrzu. Doznania fizyczne, jak np. dręczące ją po operacji pragnienie, którego nie wolno jej na razie ugasić, stara się zwalczyć, przywołując w wyobraźni obrazy z przeszłości, w których woda odgrywała istotną rolę (dzban $\mathrm{z}$ wodą, kąpiel w rzece).

Jednocześnie dyskurs ciała należy powiązać z koncepcją Tone Bringi, która pisała o utjelovljenju kuće. Według norweskiej badaczki w Bośni, zgodnie z tradycją muzułmańską, kobieta symbolicznie odzwierciedla dom, co wiąże się z jej cielesnością. Przestrzeń domowa, zapewniająca rodzinie bezpieczeństwo i stanowiąca miejsce wychowywania dzieci, jest tradycyjnie przypisana kobiecie, która w pełni ponosi za nią odpowiedzialność [Bringa 2009: 92]. Mimo jednak osadzenia bohaterki w tradycyjnym, ściśle określającym podział ról kulturowych kobiet i mężczyzn kontekście, Musabegović ukazuje jej swoistą ewolucję, jej subtelną drogę ku emancypacji (w pewnej mierze wymuszonej przez okoliczności wojenne).

Szczególnie interesująca jest ta część powieści, w której otrzymujemy zapis procesów mentalnych i emocjonalnych, zachodzących w umyśle bohaterki znajdującej się w sytuacji granicznej. Fatima jest ofiarą traumy kolektywnej spowodowanej wojną i ludobójstwem (rzezie na ludności muzułmańskiej dokonywane w górach przez czetników i przy linii kolejowej przez ustaszy). Bohaterka najpierw usiłuje izolować przestrzeń domową i chronić dzieci przed wiedzą o dokonywanych masakrach, jednak z czasem staje się to niemożliwe. Obsesja noża, którym oprawcy podrzynają gardła swoim ofiarom zaczyna się wiązać z obsesją ludzkiego mięsa. Wojenna trauma ma charakter wielokrotny, o czym Fatima mówi, stwierdzając: „klanje je postao svakodnevnica” [Musabegović 1986: 128]. Według Marii Orwid, „traumy zapełniają rezerwuar podświadomości kolektywnej. Ludzie mogą na co dzień o nich nie myśleć, natomiast podświadomie lokalizują i magazynują wszystkie te fakty, rany i blizny po nich, stale rozdzierane nowymi traumatycznymi przeżyciami" [Orwid 2009: 11]. Każda kolejna informacja albo nawet podejrzenie (np. widok zakrwawionych żołnierzy brukających zimową biel łąki widocznej z kuchennego okna), dotyczące dokonywanych w okolicy masakr, wzmacniają w bohaterce przerażenie i poczucie bezsilności. Jednocześnie zauważmy, że traumatyczne wydarzenia są przywoływane w sposób wybiórczy, ponieważ pamięć traumy powoduje fragmentaryczność narracji [Radny 2009-2011: 109]. 
Moment o szczególnym znaczeniu związany jest z tragiczną śmiercią szwagra Fatimy, Ćamila. Skutkiem tego doświadczenia będzie intruzja, czyli wdzieranie się do świadomości przeżytego urazu: obraz rozciętego gardła wielokrotnie do niej wraca, co ona komentuje: „Svijet je postao veliko prerezano grlo čovjeka” [Musabegović 1986: 182]. Fatima ma wyraźne objawy szoku potraumatycznego: na dłuższy czas popada w stan dysocjacji, który objawia się w postaci odrętwienia, dystansu, braku odczuwania emocji w reakcji na bodźce, doświadcza również derealizacji (poczucie, że rzeczywistość uległa odmianie w niejasny sposób) i depersonalizacji (niepokojące i niezrozumiałe zmiany obserwowane w sobie samym) [Popiel, Pragłowska 2009: 41]. W swych myślanych listach do ojca wyznaje: „Ludim, babo, ludim... [...] Ludim [...] hoće li iko pametan izaći iz ove klaonice?..." [Musabegović 1986: 183]. Owładnięta obsesyjną myślą o straszliwej, zadawanej nożem śmierci nie potrafi normalnie funkcjonować, każdy kęs chleba jest dla niej naznaczony śmiercią. Jednocześnie towarzyszy jej typowe dla ofiar traumy poczucie winy. Najtragiczniejsza jednak, najbardziej rozpaczliwa i zarazem najważniejsza konstatacja związana jest z nadrzędną dla niej wartością, czyli z macierzyństwem: „Smrtnike rađam, smrtnike, i to je najteže što se shvata” [Musabegović 1986: 188]. Zatem, z jednej strony, macierzyństwo stanowi główny element przeciwstawiany wojennej przemocy i wszechobecnej śmierci, z drugiej jednak nie chroni przed rozpaczą, a można nawet zaryzykować stwierdzenie, że ją wzmacnia. Fatima wyraża wieczne kobiece przeznaczenie, związane $\mathrm{z}$ braniem zbiorowego cierpienia na własne barki, ale i mówi o czymś jeszcze, o transmisji traumy na następne pokolenia:

I ova djeca, moja djeca, kao sada tvoja, umiraće jednom. I ja, mati, opsjednuta sam slikom kakva li će biti njihova smrt. Ne zamišljam im ni život, ni mladost, ni uspjeh, ni radost, ni ljubav koju će uvijek gajiti prema meni, već zamišljam kako će, i ako prežive sve ovo, umirati. Je li to normalno? [Musabegović 1986: 188]

Bohaterka Jasminy Musabegović jest świadoma konsekwencji doświadczeń, jakie stały się jej udziałem. Ma silne poczucie, że - o ile uda im się przeżyć jej macierzyństwo już zawsze będzie naznaczone piętnem śmierci, mówi, zatem o transgeneracyjnym przekazie traumy.

Fatimie towarzyszy nieustanny lęk i poczucie śmiertelnego zagrożenia, a także przeświadczenie o tym, że życie po takich doświadczeniach nigdy już nie będzie takie, jak dawniej. Biologiczna wola przetrwania jest skierowana przede wszystkim na dzieci. Traumę Fatimy wzmacnia obecność w jej domu małej, milczącej dziewczynki (muhadžerče), sieroty ocalałej z masakry, w której z ogromnym prawdopodobieństwem zginęła całą jej rodzina. Bliznę na szyi po cięciu nożem dziecko chowa pod stale noszonym szalikiem, ale Fatima - gdyby nie wzgląd na męża - najchętniej odsunęłaby dziewczynkę spoza zasięgu swego wzroku, bo każde spojrzenie na nią jest impulsem do zadawania sobie przyprawiającego 
o szaleństwo pytania o to, które z jej dzieci w sytuacji, gdyby ich rodzina padła ofiarą rzezi, pozostałoby przy życiu i jakie byłyby jego dalsze losy.

Rola społeczna i związana z nią cielesność determinują życie kobiety i strategie przerwania w czasie zagrożenia. Na pierwszym planie mieści się oczywiście kwestia podtrzymywania rodziny lub utraty bliskich, co odzwierciedla m.in. usilne staranie ochronienia własnej domowej przestrzeni przed inwazją wojennej rzeczywistości choćby poprzez mówienie o niej. Codzienna krzątanina i ucieczka we własny świat wewnętrzny mają w jakimś stopniu pomóc znieść wojenną grozę, niemniej są to tylko rozwiązania doraźne, lagodzące cierpienie, a nie je znoszące. Mąż Faty ukrywa w domu partyzantów, trudni się surowo karanym kłusownictwem, a dzieci, wiedzione naturalną ciekawością „pod przywództwem” najbardziej śmiałej spośród rodzeństwa Selmy, w starym tunelu znajdują zwłoki ofiar jednej z masakr. Na krótki czas oazę bohaterka znajduje w przydomowym ogródku. W pewnym sensie eskapistyczna postawa Fatimy zostaje jednak zweryfikowana, gdy poszukiwany przez Gestapo Nezir przyłącza się wraz z najstarszym synem, Bećirem, do partyzantów. Gdy staje się jedynym opiekunem swych dzieci, bohaterka przyjmuje postawę aktywną i zdecydowana jest zrobić wszystko, by je ochronić. W sytuacji bezpośredniego zagrożenia posuwa się nawet do zastraszenia gospodarzy domu, w którym się ukrywa.

Ważny, ocalający wymiar należy dostrzec w więzach wspólnotowych - Fata w myślach układa listy do ojca, w których daje wyraz swemu przerażeniu i poczuciu bezsilności nieuzewnętrznianym przed domownikami. Silna więź uczuciowa łączy ją z bratem Ibrahimem, którego los pozostaje nieznany. Początkowo Fatima żywi nadzieję, że udało mu się ujść z życiem z masakry nad Neretwą, jednak potem stopniowo utwierdza się $\mathrm{w}$ intuicyjnym odczuciu, że brat nie żyje. Ponadto postać przyjaciółki z dzieciństwa, Dženety, która w czasie wojny przez pewien czas przebywa w jej domu, z jednej strony zwraca jej myśli w stronę przeszłości, z drugiej - uświadamia Fatimie, jak bardzo są różne. Dženeta ucieleśnia zmysłowość, głęboką radość życia, jednocześnie jakby przekracza swój gender, gdyż jest nad wyraz opanowana, zdecydowana, energiczna i wyjątkowo odważna, działa w sposób chłodny, racjonalny nawet w najbardziej niesprzyjających okolicznościach.

W relacjach międzyludzkich Fatima zasadniczo kieruje się intuicją i przeczuciami ${ }^{6}$. W czasie wojny niejednokrotnie przewartościowuje swoje wcześniejsze opinie i sądy na temat innych (np. na temat krewnych Nezira, z którymi dawniej jej rodzina nie utrzymywała kontaktu, ale $\mathrm{w}$ razie potrzeby $\mathrm{z}$ ich strony od razu otrzymała pomoc), w sytuacji zagrożenia - mimo dzielących ją z innymi różnic

${ }^{6}$ Intuicyjnie wyczuwa np. zagrożenie ze strony Ragiba, którego podejrzewa o pedofilskie skłonności. Wprawdzie nie mówi o swych domysłach nikomu, jest jednak przekonana, że i inne kobiety podzielają jej obawy. Jedynym sposobem, by bronić się przed zakusami mężczyzny jest chronienie przed nim córek, co Fatima robi z determinacją. 
- kieruje się przede wszystkim zasadą solidarności. Godzi się milcząco nawet na działania bardzo ryzykowne (ukrywanie w domu partyzantów).

Sposób konstruowania opowieści jest w utworze Musabegović złożony: narratorką jest Fatima i jej subiektywny głos wybrzmiewa najmocniej, dając wskutek bezpośredniości relacji autentyczny i osobisty obraz jej życia i sposobu jego przeżywania, jednocześnie jednak głos narratorki splątany jest $\mathrm{z}$ głosami innych bohaterów, co z kolei zapewnia wielość perspektyw narracyjnych. Ponadto główna narratorka ma wyraźnie polimorficzny charakter, uwarunkowany swoistym rozszczepieniem podmiotu mówiącego, na co najmniej kilka „ja”: „ja” snu, „ja” choroby, „ja” dzieciństwa, „ja” ciała. Rozszczepienie podmiotu, bardzo typowe dla relacji holokaustowych [Ubertowska 2009], w przypadku Fatimy - ujawnia się ze zdwojoną mocą w traumatyzującym okresie wojny.

Sposób widzenia wojny przez boszniacką pisarkę współgra z tym, jak ją opisywała Swietłana Aleksijewicz:

„Kobieca” wojna ma swoje własne barwy, zapachy, własne oświetlenie i przestrzeń uczuć. Własne słowa. Nie ma tam bohaterów i niesamowitych wyczynów, są po prostu ludzie, zajęci swoimi ludzkimi - nieludzkimi sprawami. I cierpią tam nie tylko ludzie, ale także ziemia, ptaki, drzewa. Wszyscy, którzy żyją z nami razem na tym świecie. Cierpią bez słów, a to jest jeszcze straszniejsze... [Aleksijewicz 2015: 9-10]

Kobiece poczucie solidarności z tymi, którzy cierpią akcentuje także Jasmina Musabegović, a z jej powieści, będącej typową realizacją kobiecej historii (herstory / ženska priča), wyłania się niebezpośrednia, ale bardzo czytelna ocena wojny. Według pisarki to kobiety są jej prawdziwymi ofiarami, przegranymi na wojnie, która zmienia je w nieodwracalny sposób, o czym Fatima mówi lakonicznie: „Žene gube rat, oni preživljavaju" [Musabegović 1986: 180]. Jest to w istocie antybohaterska narracja kobiet i ofiar wojny, nie ma tu odniesień ideologicznych. Kategoria bośniackiej matki zestawianej przez Ingę Iwasiów na zasadzie analogii z Matka Polka [Iwasiów 2008: 127], w powieści Skretnice jest nieobecna, co wzmacnia poczucie naruszenia systemu patriarchalnego. Kobieta, stanowiąca symboliczne centrum rodziny i wspólnoty, kulturowo pełni zasadniczą rolę w pielęgnowaniu i przekazywaniu tradycji. Personifikując trwanie i niezmienność, jest gwarantem tożsamości, tymczasem tutaj dokonuje transgeneracyjnego przekazu traumy, co oznacza zaprzeczenie patriarchalnego porządku i dekonstrukcję epickiego kodu kulturowego, o czym sugestywnie pisała Nirman Moranjak-Bamburać [Moranjak-Bamburać 2006; Moranjak-Bamburać 2005b]. Choć w pewnym stopniu boszniacka autorka potwierdza patriarchalny porządek i w jego ramach kobiecą rolę uwarunkowaną płcią (naturalna predyspozycja do bycia osobą chroniącą dom, tradycję i język - čuvarica doma, tradicije i jezika), to przede wszystkim jednak postrzega kobietę jako pośredniczkę w przekazie transgeneracyjnej traumy. 
Wpływ tej traumy na życie rodziny, na relacje wewnątrzrodzinne w omawianej powieści ukazany jest $\mathrm{w}$ zarysie, $\mathrm{w}$ większym zaś stopniu podlega analizie w dwóch kolejnych częściach trylogii (Most, Žene. Glasovi) i bez wątpienia jest to temat wart zglębienia. Kobieca historia wojny, którą pisze Musabegović pokazuje, bowiem nie tylko inne jej oblicze, ale też i inne, dalej i głębiej sięgające konsekwencje wojny niż te, które zostały dotąd opisane z męskiej perspektywy [Łucka, Nowak 2014; Nowak, Łucka 2014; Orwid 2009; Schier 2015].

\section{LITERATURA}

[Aleksijewicz 2015] - S. Aleksijewicz, Wojna nie ma w sobie nic z kobiety, przeł. J. Czech, Wydawnictwo Czarne, Wołowiec.

[Bringa 2009] - T. Bringa, Biti Musliman na bosnaski način. Identitet $i$ zajednica u jednom srednjobosnaskom selu, przeł. S. Krešo, Dani Sarajevo, Sarajevo-Zagreb.

[Duraković 2012] - E. Duraković, Obzori bošnjačke književnosti, Dobra Knjiga, Sarajevo. [Hawkesworth 2000] - C. Hawkesworth, Voices in the Shadows. Women and Verbal Art in Serbia and Bosnia, Central European University Press, Budapest.

[Iwasiów 2008] - I. Iwasiów, Gender dla średnio zaawansowanych. Wykłady szczecińskie, Wydawnictwo W.A.B., Warszawa.

[Jawoszek 2014] - A. Jawoszek, Boszniacy. Literackie narracje tożsamościowe po 1992 roku, Wydawnictwo Nauka i Innowacje, Poznań.

[Kazaz 2004] - E. Kazaz, Bošnjački roman XX. vijeka, Naklada Zoro, Zagreb-Sarajevo.

[Łucka, Nowak 2014] - I. Łucka, P. Nowak, Wtosy babci - trauma transgeneracyjna, „Psychiatria - Psychologia Kliniczna", nr 14.

[Moranjak-Bamburać 2005a] - N. Moranjak-Bamburać, Czy jest wojna w piśmie wojennym?, [w: ] Literatury stowiańskie po roku 1989. Nowe zjawiska, tendencje, perspektywy, t. 3: Podmiotowość, red. B. Czapik-Lityńska, Dom Wydawniczy Elipsa, Warszawa.

[Moranjak-Bamburać 2005b] - N. Moranjak-Bamburać, Nevolje s kanonizacijom, „Sarajevske sveske", br. 8-9, http://www.sveske.ba/bs/content/nevolje-s-kanonizacijom (13.02.2013).

[Moranjak-Bamburać 2006] - N. Moranjak-Bamburać, Trauma - memorija - pripovijedanje, „Sarajevske sveske”, br. 13, http://www.sveske.ba.bs/content/trauma-memorija-pripovijedanje (2.11.2012).

[Musabegović 1986] - J. Musabegović, Skretnice, Veselin Masleša, Sarajevo.

[Nowak, Łucka 2014] - P. Nowak, I. Łucka, Młody Polak po doświadczeniach wojennych. Siła transgeneracyjnej transmisji traumy, „Psychiatria - Psychologia Kliniczna”, nr 14.

[Orwid 2009] - M. Orwid, Trauma, Wydawnictwo Literackie, Kraków.

[Popiel, Pragłowska 2009] - A. Popiel, E. Pragłowska, Psychopatologia reakcji na traumatyczne wydarzenia, [w:] Konsekwencje psychiczne traumy. Uwarunkowania i terapia, red. nauk. J. Strelau, B. Zawadzki, M. Kaczmarek, Wydawnictwo Naukowe Scholar, Warszawa.

[Radny 2009-2011] - A. Radny, Wplyw traumy na psychikę. Psychoterapia ofiary, „Neurokognitywistyka w patologii i zdrowiu", nr 1. 
[Schier 2015] - K. Schier, Dorosłe dzieci. Psychologiczna problematyka odwrócenia ról $w$ rodzinie, Wydawnictwo Naukowe Scholar, Warszawa.

[Ubertowska 2009] - A. Ubertowska, „Niewidzialne świadectwa”. Perspektywa feministyczna w badaniach nad literatura Holokaustu, „Teksty Drugie”, nr 4.

\author{
Anna Modelska-Kwaśniowska
}

\title{
WOMEN'S EXPERIENCE OF WAR TRAUMA IN JASMINA MUSABEGOVIC'S NOVEL SWITCHES
}

\author{
(Summary)
}

Jasmina Musabegović (born 1941) is one of the best contemporary prose writers and essayists in Bosnia. In her work she sets the position of women in BosnianHercegovinian society and the women's personal experience of the $20^{\text {th }}$ century. It is the history of women's emancipation and their alienation too.

The story is set in the thirties and forties of the $20^{\text {th }}$ century in Bosnia. The main character is a young Muslim woman, Fatima. Fictional space is mainly created by home and its center - the kitchen, which is traditionally a space assigned to women. Fatima is the victim of a collective trauma caused by war and genocide. The memory of the trauma causes a fragmented narration and the splitting of the subject speaking to some "me".

The main scene of the story is Fatima's body with typically feminine symbols and themes (water, land, bread). The discourse of the body should be linked with the concept of Tone Bringa (utjelovljenje kuće - a materialization of home), according to which the woman symbolically reflects the house, which is associated with its physicality. It also serves to release the experiences impossible to verbalize, including traumatic experiences of war.

Switches are a typical herstory. Jasmina Musabegović confirms the patriarchal order in a way, but eventually presents the woman as a mediator in the transgenerational transmission of trauma, which means denial of the patriarchal order and breaking the epic cultural code. 